\title{
How could anyone forget Harold W. Berkman?
}

\author{
Barry J. Babin ${ }^{1} \cdot$ Nina Krey² \\ Accepted: 13 October 2021 / Published online: 28 October 2021 \\ (c) Academy of Marketing Science 2021
}

People often say when someone passes away as they approach the century mark, "they certainly lived a full life." Well, one might be tempted to say the same for Harold W. Berkman, Ph.D., the Academy of Marketing Science (AMS) Founding Fellow and Distinguished Professor of Business. Harold passed away on December 7, 2020, at the age of 94. However, saying that Harold lived $a$ full life does not completely capture his many contributions; contributions that enrich the lives of countless people today and will continue to do so for generations to come. Harold was the AMS Executive Vice-President and Director from its creation in 1971 until the day he passed away. The 50 years of service epitomizes his energy, work ethic, and also his selflessness, as he was somewhat uncomfortable with public acclamation for his accomplishments. No, Harold did not have "a full life;" he had no less than three full lives in one lifetime. Harold served with distinction as a soldier, an entrepreneur, and as a scholar.

Clearly, those of us lucky enough to know him personally realize that he was not a person that would be easy to forget! However, this homage allows readers a unique glimpse into his accomplishments and contributions. While relatively few people may be aware of the man behind AMS, many have benefitted from his leadership. Especially his effort and dedication to this journal deserve to be acknowledged-without Harold, the Journal of the Academy of Marketing Science (JAMS) would not exist. Harold did more than lay the foundation for an elite Journal, he built it, and then oversaw it through the rest of his life.

Harold's many contributions can teach us so much as professional marketing academics or practitioners today. His

Barry J. Babin

bbabin@bus.olemiss.edu

Nina Krey

krey@ rowan.edu

1 University of Mississippi, University, MS 38655, USA

2 Rowan University, Glassboro, NJ 08028, USA focus remained always on the result whether for the country, a business, AMS, or for the discipline. Professionalism is embodied in his motivation to serve without concern for acclamation. The Academy depends on service, and often the most important type of service is thankless and remains unknown to those that benefit. Appropriately, the prestigious AMS Academy Award for Distinguished Service bears his name. Well, Harold, if you were not thanked enough for your contributions while you were on the Earth, we trust you are finding your share of gratitude now. This editorial is a reminder of your service and contributions.

\section{Staff Sergeant Harold W. Berkman: the soldier}

Harold's youth was cut short by WWII. His wartime experiences greatly impacted his life and provided a motivation for service. Harold's family was a first-generation American family. ${ }^{1}$ His parents immigrated to the United States (U.S.) from Belarus in the early $20^{\text {th }}$ century. He was extremely proud to be an American. Like so many in the Greatest Generation, he did not have time to ease into adulthood. At the age of 18, in 1944, Harold was drafted into the U.S. Army and was sent to England aboard the Queen Elisabeth to await deployment in the European theater of operations. Thus, at an age younger than the majority of freshman college students, he faced grim realities that left no room for immaturity.

He served proudly in General George Patton's $3^{\text {rd }}$ Army, starting in the $36^{\text {th }}$ Infantry Battalion and joining Patton's army at Bastogne in the $80^{\text {th }}$ Infantry Battalion during the Battle of the Bulge. Fresh out of high school, he faced enemy fire, walked through mine fields, observed the horrors of

\footnotetext{
${ }^{1}$ Harold documents his own experiences as a soldier in a video history available from the WWII museum in New Orleans, where the Berkmans are patrons (https://www.ww2online.org/view/haroldberkman). Readers are highly encouraged to view the video available there to get to really know Harold-ever authentic.
} 
war, but through it all he continued to serve; and through it all, he survived from one fox hole to another. He also helped liberate Buchenwald concentration camp. For his actions during deployment, he received numerous service awards including the Bronze Star for meritorious achievement in combat, a Presidential Unit Citation, the Order of Saint Maurice Medal, and the Chevalier de la Légion d'Honneur (from the French government). However, he was most proud of the U.S. Army's Combat Infantryman Badge, a badge awarded to Infantrymen who engage in combat action-the grunts of war.

Those experiences, like so many of his generation, instilled in him a practical, no-nonsense, success-driven demeanor that would carry him through years. Even in later years, he would not run from a dispute. He was never one to hesitate to say exactly what was on his mind. One always knew where they stood with Harold! However, underneath the straight-forward demeanor, was also a deep compassion for others. Surely, his wartime experiences shaped his postwar grit, his gratitude, his compassion, and his motivation for service.

\section{Harold W. Berkman: entrepreneur and founding fellow}

Upon Harold's return to the U.S. from Europe, the most important event in his life was getting married to his childhood sweetheart. He postponed the wedding until he earned a college degree. Harold is survived today by Muriel Siegel Berkman after nearly three-quarters of a century of married life. Arriving in the U.S. as immigrants, both Harold and Muriel's fathers got involved in any type of small business that would pay bills. Harold's family had found success in the scrap metal business early in the $20^{\text {th }}$ century and Muriel's family got involved in retail gas stations. Harold was eager to follow their lead and get involved in business. He headed south to the University of Georgia to earn a bachelor's degree in business. Why Georgia? "because I could finish the degree in three years," he liked to say. He was not one to put things off. Returning to New York with degree in hand in 1949, he joined the family businesses and married Muriel in 1950. Starting his own business ventures, he opened and managed a chain of liquor stores (Valencia Liquor) in the New York City area. Without that particular first-hand business experience, this journal would have had a short shelf-life as we see below.

Not the least of his achievements as an entrepreneur and businessman was the creation of AMS and JAMS. After entering an Academic career fulltime, Harold realized a void existed in that many marketing faculty felt under-served by the American Marketing Association (AMA). He got the impression that the AMA had come to be perceived as elitist, particularly among those not at the most prestigious institutions. Thus, in 1971 he founded the AMS. Mainly, he worked his phone at C.W. Post, Long Island University, to recruit participation and managed to grow the association to one consisting of hundreds of "Fellows." The term Fellow was adopted for members, in what turned out to be a successful effort, to create a sense of comradery and approachability amongst the membership. He created the AMS motto of fiat lux (let there be light—enlighten) and the AMS motivation of fostering "a business world of substantial competence, judicious professional dignity, and high moral persuasion" (www.ams-web.org).

To expand the membership, he personally invited Canadian marketing academics to participate and contribute. A successful telephone and letter-writing campaign brought forth a healthy membership from Canada. The open outreach represented an important illustration of the welcoming nature of AMS. Later, the association would develop formal articles of confederation and bylaws and begin holding domestic conferences annually, and eventually, host the World Marketing Congress (first biannually then annually). The first AMS Annual Conference was held in Akron, Ohio in 1977 and the first World Marketing Congress was held in Halifax, Nova Scotia (Canada) in $1983 .{ }^{2}$

Not to be one to leave well-enough alone, a professional association of researchers needs an outlet to share the research it produces. Thus, not long after the birth of the AMS, he created a journal for AMS members that would become, perhaps arguably, as influential a marketing academic journal as exists-JAMS. Neither he, nor the first editor he named, Jane Fenyo, had experience in running an academic journal (Berkman, 1992). But together, with the help of work study students, they somehow managed to attract enough content to sustain the journal in its early years. He credits Fenyo, whose background was in English, with working many late nights to turn submissions into publishable quality manuscripts. Also, the appointment of Jane Fenyo as Editor was bold as she became the first woman to hold such a position in the discipline. Harold was successful in gaining a substantial interest in JAMS in the Canadian community to bolster the submission count. For the record, the first article appearing in JAMS addressed the Canadian perspective on the marketing mix (Banting \& Ross, 1973). Harold's efforts at welcoming international participation were already paying off.

\footnotetext{
2 AMS hosted a Symposium in 1976 where the first Awards Banquet was held and honored Paul B. Townsend, Editor and Publisher of the L.I. Business Review, with the first AMS Academy Award. The symposium consisted primarily of business professionals with an audience that included academics and other presenting professionals. The symposium is documented in the 1976 volume of JAMS: https://doi. org/10.1007/BF02729779.
} 
AMS membership dues have always been very low. Thus, they did not generate enough revenue to financially support $J A M S$. Ever the businessman, how could he generate revenue to support the costs of printing, marketing, and mailing hundreds of journals? He reached back to his Valencia Liquor resources and recruited wine marketing professionals to host wine classes. Class attendees paid a fee to learn about and sample wines while the wine companies were able to promote their wines/products. Harold, in turn, used the profits to support the Journal until library subscriptions grew in later years to make JAMS sustainable. Thus, the skills of a true marketing entrepreneur underlie the history of JAMS. Fittingly, from the late 1990s through the early 2000s, the AMS Annual Conference featured a wine marketing session that was a highlight of those conferences. Even today, wine marketing sessions are still one of the most popular and cherished events at AMS conferences. Eventually, JAMS became the biggest source of revenue for AMS, and, along with "prudent" management under the watchful eye of Harold W. Berkman, provided the Association with financial stability. Despite the low membership fees, AMS Fellows have always received a subscription to JAMS at no extra expense.

Harold never truly retired. He left the Vice-Dean's Office at the University of Miami at the age of 81 but remained active in managing AMS affairs until his death. In his later years, he created the Harold and Muriel Berkman Charitable Foundation (https://berkmanfoundation.org/foundation/). The Foundation is a way that he and Muriel can support initiatives that matter the most to them for many years to come. These efforts are made possible through successes in business. Since the first awards were given in 2014, nearly $\$ 400,000$ has been awarded to support three causes. First, to advance the marketing discipline by awarding scholarships to students majoring in marketing at AACSB accredited institutions. Second, to provide research grants for promising marketing research scholars. Third, and most dear to his heart, to provide scholarships for U.S. Military Veterans. The priority for receiving a scholarship in the latter category puts the most weight on an applicant holding the U.S. Army Combat Infantryman Badge, demonstrating how proud he was to have been an ordinary GI that fought for his country. Through his daughter, Karen Berkman, who assumed the role of President of the Foundation on Harold's passing, the entrepreneurial efforts by Harold in creating the Foundation will live on.

\section{Professor Harold W. Berkman: Scholarly career}

Harold's entrepreneurial and scholarly achievements are intertwined, as we can see above. Had he never attended graduate school, he likely would have focused his service on things other than an academic professional association. During the 1960s, before entering academia, Harold spent some time as a marketing executive for large corporations in the New York/Connecticut area. Feeling the need for a new challenge, he entered graduate school and received his MBA (1969) and Ph.D. (1971) from St. John's University in New York. After more than 20 years of business experience, his academic career started as an adjunct professor at C.W. Post (Long Island University) in 1969 where he was soon promoted to Associate Professor (1970). In 1977, he moved on to the University of Miami and was later promoted to Vice Dean of Graduate Programs. He ran a successful executive education program for more than twenty years later. During those years, the AMS was based out of the University of Miami.

As a scholar, Harold authored over a dozen books. Most notably, he was an early author in the consumer behavior era with a book titled, Consumer Behavior Concepts \& Strategies. The book was first published in the mid-1970s and continued in circulation into the 2000s, when Joe Sirgy and Jay Lindquist became coauthors. However, the book was originally coauthored by Christopher Gilson, an executive for Doubleday Advertising and later, for Rapp \& Collins (Berkman \& Gilson, 1976). Thus, we clearly see how important the practitioner side of marketing remained to Harold even as he transitioned into academia as further evident in positioning JAMS as a bridge between marketing practice and marketing academics (Berkman, 1992).

Harold also published his share of scholarly journal articles. Airline safety was an important issue to him that he turned into a research pursuit (Berkman et al., 1982). His years in the corporate world also provided expertise that allowed him to contribute to the then controversial area of advertising in the legal profession. His desire for business to be ethical also shows in that he was an early advocate calling for more research into professional and ethical practices in marketing (Berkman, 1977).

Clearly though, Harold's legacy to academia is the Academy of Marketing Science, which provides scholars a place to present research, exchange ideas, network, form friendships, and become part of the AMS community. By creating AMS, he also left JAMS and AMS Review as part of that legacy. By some performance and citation metrics, JAMS is the leading journal in the discipline today. The 2020 InCites Journal Citation Report produced by Clarivate lists JAMS with the highest 5-year impact factor (21.3), and in three of the past four years it has also had the highest 2-year impact factor among all marketing journals. AMS Review is the leading marketing journal for conceptual research and theory development. In the sense of the AMS legacy, his academic impact is equaled by few in the marketing discipline and his impact will continue as long as the discipline exists. Most definitely, he had reason to be proud of all of his careers and 
his life (lives) in general. Harold Berkman, we are grateful are grateful to your service as a soldier, as a businessman, and as a scholar. Most of all, we are grateful for your service and for giving service to country, family, and academia such a high priority.

\section{Conclusion: Harold W. Berkman lives on}

For those affiliated with this Journal, this essay serves as a proper thank you from AMS for continuing to make such a great impact on our lives. All of us who love freedom thank you for helping us keep it. Additionally, the hundreds of students who received and will receive scholarships from the Berkman Foundation surely feel a debt of gratitude as do the dozens of marketing academics benefiting from research grants that bear his name. Especially, every author whoever contributed to JAMS, or will ever contribute to JAMS, as well as every reader whoever benefited from JAMS, also is indebted to Harold.

Harold, you are unforgettable.

Acknowledgements The authors would like to thank Jay Lindquist and O.C. Ferrell for valuable input based on their review of a draft of the manuscript. Both Jay and O.C. were among those of us who knew Harold particularly well.

\section{References}

Banting, P. M., \& Ross, R. E. (1973). The marketing mix: A Canadian perspective. Journal of the Academy of Marketing Science, 1, 1-11. https://doi.org/10.1007/BF02729310

Berkman, H. W. (1977). Corporate ethics: Who cares? Journal of the Academy of Marketing Science, 5, 154-167. https://doi.org/10. 1007/BF02729499

Berkman, H. W., Chusmir, L. H., Gitlow, H. S., \& Hertz, P. (1982). Airline safety: Perceived and actual. Journal of the Academy of Marketing Science, 10, 514-538. https://doi.org/10.1007/BF027 29351

Berkman, H. W. (1992). Twenty years of the journal. Journal of the Academy of Marketing Science, 20(4), 299-300.

Berkman, H. W., \& Gilson, C. C. (1976). Social class and consumer behavior: A review for the 70's. Journal of the Academy of Marketing Science, 4, 644-657. https://doi.org/10.1007/BF02729777

Publisher's note Springer Nature remains neutral with regard to jurisdictional claims in published maps and institutional affiliations. 